\title{
Effect of Technology Based Customer Relationship Management on Satisfaction of Commercial Banks' Account Holders in Nairobi City County, Kenya
}

\author{
Rael N. Mwirigi \\ Department of Business Administration, Faculty of Business Studies, Chuka University, Kenya \\ P.O.Box 109-60400, chuka, Kenya
}

\begin{abstract}
The objective of this study was to establish the effect of technology based Customer Relationship Management (CRM) on satisfaction of commercial banks account holders in Kenya. The study adopted a cross-sectional research design involving descriptive and explanatory research techniques. The target population was 34,649,583 account holders out of which a sample of 400 respondents were selected using mixed sampling techniques. Data was collected using a questionnaire and analyzed using both descriptive and inferential statistics. Simple linear regression was conducted to assess the relationship between technology based CRM and account holder satisfaction. The study established that technology based CRM had a statistically significant effect on satisfaction of commercial banks account holders. The study recommends that commercial banks management should consider technology based CRM dimensions when developing strategies because they have a significant effect on account holder satisfaction with commercial banking services. Commercial banks in Kenya and the central bank can use the findings of this study to formulate technology based CRM policies that enhance service delivery, customer satisfaction and performance. To increase the level of generalization and objectivity, future studies should be carried out in other service industries such as insurance, airlines and medical services using additional variables and a different design such as time series.
\end{abstract}

Keywords: Technology based customer relationship management, account holder, satisfaction, commercial banks DOI: $10.7176 / \mathrm{EJBM} / 11-9-09$

Publication date:March $31^{\text {st }} 2019$

\subsection{Introduction}

Customer Relationship Management (CRM) refers to an integrated approach to practices and technologies that aim at customer retention through effective management of relationships with customers as opposed to transactionbased marketing (Christopher, Payne \& Ballantyne, 1991). It comprises a company-wide, cross-functional and customer-focused business processes that involve people and technology (Chan \& Popovich, 2003). Hence, technology applications link the company's front office and back office functions with the company's customer contact points such as internet, e-mail, call centres and advertising which aim at enhancing customer satisfaction (Fickel, 1999, Eckerson \& Watson, 2000).

Parvatiyar and Sheth (2002) on the other hand argue that CRM is a strategy and process of acquiring, retaining and partnering with customers in order to create superior value for both parties. Similarly, Thakur, Summey and Balasubramanian (2006) posit that CRM involves elements of marketing, sales, services, operations and information technology (IT) which aim at understanding the behaviour and needs of customers. As a business strategy, CRM incorporates processes, functions and networks that deliver value to customers at a profit. It also helps firms to acquire new customers, satisfy and retain them so as to maximize their lifetime value (Buttle, 2006). Payne and Frow (2005) describes creation of value as a process which involves co-creation of value by both companies and customers as well as management of interactions using technology. Technology based CRM involves identification and interaction with customers, differentiation and customization of products and services. Sin, Tse and Yim (2005) proposed that successful implementation of CRM should be measured in terms of customer focus, CRM organization, knowledge based CRM and technology based CRM. Technology based perspective of CRM is concerned with availability of technology as an enabler in CRM implementation that facilitates the organization to customize services, increase efficiency in service delivery and reduce costs (Sin et al., 2005). It also focuses on customers' satisfaction through transformation of the organizational structure, processes, culture and technology (Peppers, Rogers \& Dorf, 1999).

Customer satisfaction involves cognitive and affective responses which result from service encounters (Fecikova, 2004). The cognitive component refers to the customer's evaluation of the perceived performance in terms of adequacy in comparison to customer's expectation standards. The affective component is the emotional aspects such as happiness, surprise, and disappointment. Further, Hansemark and Abinson (2004) assert that satisfaction is an overall customer attitude arising from the differences between service providers' performance and perceived quality expectations regarding the fulfillment of needs, goals and desires. As indicated by Jeong and Lee (2010), customer satisfaction represents emotions, reactions and experiences of a customer towards offerings 
of a service provider. Further Boone and Kurtz (2013), argue that customer satisfaction represents the customers' voice regarding their appraisal of the extent to which services meet or exceed their expectations.

In this study, customer satisfaction is described as the overall assessment of a customer's experience after a service encounter with a commercial bank. The banking industry in Kenya is guided by the Company's Act, (Cap 486, 2008), Banking Act (Cap 488, 2012) and the various prudential guidelines issued by the Central Bank of Kenya. Banks in Kenya are faced with challenges of new requirements generated by increased use of ICT to facilitate delivery of quality services. Information technology has replaced manual processes and related controls resulting in increased cases of ICT frauds related to use of computer, mobile and internet based online transactions (CBK 2014). Therefore, for banks to remain financially competitive in the ever-changing market environment, they need to design services that leverage on ICT, such as customer relationship management that can deliver accurate and timely services and information to customers. In the contemporary banking sector, customers have access to unlimited information via ICT and are searching for a one-stop financial partner that can meet all their financial needs.

Moreover commercial banks are also increasingly offering electronic banking service such as Automated Teller Machines, mobile banking, and websites that facilitate customers to obtain information about their accounts, pay bills; open new accounts and make funds transfer (CBK, 2015). In addition, banks have embraced use of information communication technology (ICT) to enhance quality service delivery and customer satisfaction as survival strategies. These new developments in ICT have resulted in customer demand for quality service where deviation from service expectations lead to bank switching and customers with multiple accounts in different banks (Maina, 2014). This raises concerns over the level of customer satisfaction with services rendered by commercial banks in Kenya. The current study therefore, focused on the effect of technology based CRM on customer satisfaction among account holders of commercial banks in Kenya.

\subsection{Objective of the Study}

The objective of this study was to establish the effect of technology based CRM on satisfaction of commercial banks account holders in Nairobi City County, Kenya.

\subsection{Review of Related Literature}

Implementation of CRM is partly dependent on banks' investments in technology based CRM which enables customers to access information and services. The CRM based technologies largely support banks processes of gathering customer information, decision making and faster communication (Marko, Sanader, Laketa \& Misic, 2015). The application of appropriate technologies that are in line with organizational objectives facilitate development of high quality customized offerings, lower costs and improve employee performance at customer contact points (Boyle, 2004). Technological advancements also enhance gathering and analyzing information about competitors, customers and other stake holders and such information is shared among departments to aid in customization of the needed products and services. Some of the recent technology based CRM tools utilized by companies include data mining, computer aided manufacturing and design, data warehouses and software systems that aim at higher quality and customization of offerings that satisfy consumer needs (Sadek \& Tantawi, 2009; Bouguerra \& Mzough, 2011).

The banking industry has always relied on technology to acquire process and deliver services to customers. The use of IT facilitates banks in processing of information, service differentiation and provides convenient, reliable and expedient services (Tan \& Teo, 2000). In addition banks have also invested heavily in technological self-service technologies (SST) such as ATMs, telephone, Debit and credit cards, home banking via telephone or personal computer which are convenient touch points for interaction between customers and their banks that are managed through personalized branch and technology enabled encounters (Siam, 2006). Jain, Jain and Dhar (2007) suggested that companies should select the right technology and install it in customer contact points. Similarly, Sin et al., (2005) proposed the use of up to date technology to enable organizations to develop computerized communications and technology aligned with business processes, higher quality service and better performance at customer contact points.

Roy and Ganguli (2011) examined the effect of generic technology based service quality dimensions on customer satisfaction among customers from different banks in the USA. The study found that technology ease of use, its reliability and customer service have a positive and significant effect on customer satisfaction. The study further established that technology convenience and customer satisfaction have a positive and significant effect on loyalty to the bank. In a study by Narteh (2014) assessed the effect of perceived service quality on customer satisfaction with self- service technology (SST) in retail banking sector in Ghana. The study focused on automated teller machines (ATM) service quality dimensions. The study established that ease of use, reliability, responsiveness, fulfillment and convenience of services predicted customer satisfaction. This finding is in agreement with a position held by Khan (2010) who noted that ATM service quality is positively associated with satisfaction. However, ATM security and privacy did not have a significant effect on customer satisfaction. The 
study recommended further studies in other self-service technologies to enhance understanding of SST dimensions effect on customer satisfaction.

Salhieh, Doleh and Hjazi (2011) assessed e-readiness of banks in Jordan to provide e-banking services. The study used the perception of bankers and customers to assess IT infrastructure support on e-banking readiness. Customer acceptance indicators used in the study were perceived ease of use, usefulness, privacy, enjoyment and security. Regarding IT infrastructure in the bank, the components considered were IT personnel and connectivity, functionality of application and compatibility. The results of the study showed that e-banking has achieved a degree of operational and strategic importance and that customers are positive about embracing e-banking. The study proposed a framework to evaluate banks' readiness for e-banking services.

Sadek and Tantawi (2009) examined the effect of customer focus CRM, CRM organization, knowledge and technology based CRM on customer satisfaction in the Egyptian banking sector. The findings indicated that the selected banks have adopted customer focus CRM, CRM organization, knowledge management and technology based CRM. The study also established that the level of CRM implementation differs from one banks to another and revealed a significant relationship between CRM and customer satisfaction when the four components are applied together. The study did not assess the effect of the individual CRM components on customer satisfaction. The current study however assessed the effect of technology based CRM on satisfaction of commercial banks account holders.

\subsection{Research Methodology}

This study was guided by positivistic research philosophy. In line with the positivist approach this study adopted a quantitative approach in examining the relationships between variables and formulated research hypotheses, tested them for their validation and subsequent generalization (Saunders, Lewis \& Thornhill, 2009). This study adopted both descriptive and explanatory research design which was cross-sectional in nature. According to Copper and Schindler (2003), cross-sectional research design aims to obtain accurate data from respondents at a specific point in time. The target population was 34,649,583 account holders from all commercial banks in Kenya which were categorized as large, medium and small (CBK, 2015). The study collected primary data from account holders of commercial banks in Nairobi headquarters branches using a structured questionnaire. A sample size of 400 was determined using Yamane (1967) formula for calculating the sample size from a finite population.

$$
n=\frac{N}{1+N(e)^{2}}
$$

$\mathrm{e}$ is the allowed margin of error $=0.05$, hence $\mathrm{N}=34,649,583, \mathrm{n}=400$

\subsection{Validity and Reliability of Data Collection Instrument}

The study used Cronbach's alpha coefficient to check the reliability of the instrument which was recommended by Malhotra,Hall,Shaw and Oppenheim, (2002) as a standard measure of inter item consistency reliability. The research instrument attained Cronbach's alpha coefficient of 0.9 , which is regarded as reliable as recommended by Field (2009). Quantitative data were analyzed using both descriptive and inferential statistics in Statistical Package for Social Sciences (SPSS) version 19. Simple linear regression analysis was carried out to establish the effect of technology based CRM on account holder satisfaction. The linear regression model was stated as follows:

$$
C S=\beta_{0}+\beta_{1} T B+\varepsilon^{\prime}
$$

Where; $\mathrm{CS}=$ Composite index of customer satisfaction, $\beta_{0}=$ constant, $\beta_{1}=$ Regression coefficient,

$$
\mathrm{TB}=\text { Technology based CRM, } \varepsilon^{\prime}=\text { Error term }
$$

\subsection{Results and Discussion}

The study collected data from 400 commercial bank account holders, out of which 336 were found to be suitable for further analysis. This constituted a response rate of 84\%. According to Rogelburg and Stanton (2007), a response rate of $35 \%-40 \%$ is appropriate for studies conducted at the organizational level. The aggregate mean score for technology based CRM responses was 3.74. This implies that respondents were of the opinion that technology used by commercial banks such as automated services and mobile banking were easy to use, convenient and accessible. This shows that commercial banks in Kenya have embraced technology based CRM

\subsection{Effect of Technology Based CRM on Customer Satisfaction}

To examine the effect of technology based CRM, the study conducted simple regression analysis and tested the following hypothesis; The regression results are shown in Table 1 (a-c). 
Table 1(a): Model Summary

\begin{tabular}{|c|c|c|c|}
\hline $\mathrm{R}$ & $\mathrm{R}^{2}$ & Adjusted $\mathrm{R}^{2}$ & Std. Error of the Estimate \\
\hline $.663^{\mathrm{a}}$ & .440 & .438 & .54110 \\
\hline
\end{tabular}

Source: Survey Data (2017)

The results in Table 1 (a) show an adjusted $\mathrm{R}^{2}=0.438$ indicating that technology based CRM explained $43.8 \%$ change in customer satisfaction in commercial banks.

Table 1 (b) shows the results for the overall significance of the model for technology based CRM and customer satisfaction.

Table 1 (b): ANOVA

\begin{tabular}{|l|l|l|l|l|l|}
\hline & Sum of Squares & Df & Mean Square & F & Sig. \\
\hline Regression & 74.684 & 1 & 74.684 & 255.078 & $.000^{\mathrm{a}}$ \\
\hline Residual & 95.156 & 325 & .293 & & \\
\hline Total & 169.839 & 326 & & & \\
\hline
\end{tabular}

Source: Survey Data (2017)

The results in Table 1 (b) indicate that overall significance of the model was statistically significant with $\mathrm{F}=255.078$ and $\mathrm{P}$-value $=0.000(\mathrm{P} \leq 0.05)$. This implies that technology based CRM had a statistically significant effect on satisfaction of account holders in commercial banks. The coefficient results of CRM and customer satisfaction in Table 1 (c) indicate the significance of the linear regression model of technology based CRM and customer satisfaction.

Table 1 (c): Regression Coefficients

\begin{tabular}{|l|l|l|l|l|l|}
\hline & Unstandardized Coefficients & Standardized Coefficients & T & \multirow{2}{*}{ Sig. } \\
\hline & B & Std. Error & Beta & & \\
\hline $\begin{array}{l}\text { (Constant) } \\
\text { Bechnology } \\
\text { Based CRM }\end{array}$ & .948 & .153 & & 6.178 & .000 \\
\hline
\end{tabular}

Source: Survey Data (2017)

The results in Table 1 (c) show a computed composite score of technology based CRM of 0.645 and Pvalue $=0.000(\mathrm{P} \leq 0.05)$. This implies that a unit change in technology based CRM affect customer satisfaction by a factor of 0.645 . The results reject the null hypothesis and conclude that technology based CRM has a significant effect on satisfaction of commercial banks' account holders in Nairobi County. These findings conform to Roy and Ganguli (2011) who found that technology ease of use, reliability, convenience and customer service had a positive and significant relationship with customer satisfaction. These findings also support Thuo (2011) who found that commercial banks in Kenya had implemented CRM and had adopted technology to a moderate extent.

The prediction regression model was restated as:

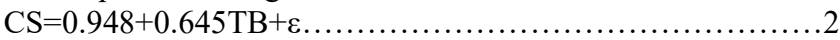

\subsection{Conclusion and recommendations}

Customer satisfaction has been a critical issue of concern among commercial banks because satisfied customers are valuable assets that translate to profitability and competitiveness of commercial banks. This realization has compelled commercial banks to implement various strategic measures to enhance customer satisfaction which affects sustainability and survival in the competitive financial sector. To maintain and build long term relationships with account holders, commercial banks have implemented technology based CRM strategies that focus on enhancing customer satisfaction. In this regard, the objective of this study was to empirically establish the effect of technology based CRM on satisfaction of commercial banks account holders in Kenya. The study established that technology based CRM had a positive and statistically significant effect on satisfaction of commercial banks accounts holders. Therefore, the null hypothesis was not supported by the study. This implies that commercial banks have invested heavily on technology based CRM which is customer friendly, convenient and accessible.

This study contributes to new knowledge by conceptualizing variables previously studied differently such as CRM and customer satisfaction. Therefore, the study identifies some of the knowledge gaps cited in the literature and contributes to the frontiers of knowledge related to CRM and satisfaction of account holders' in the banking sector. Specifically, the study measured customer satisfaction in terms of positive experience with bank customers, preference for banks products and services, image of the bank and its accessibility that reveal the feelings of customers as opposed to customer loyalty, repeat purchase and advocacy measures used in previous studies to assess the behavior of customers. Finally, this study makes significant contribution to the advancement of academic knowledge and theory on CRM and customer satisfaction in the context of the financial sector in an African setting. The literature reviewed clearly shows insignificant scholarly studies on technology based CRM and satisfaction from the African banking sector. Therefore, this study contributes to literature on CRM and 
customer satisfaction by providing empirical evidence on the effect of technology based CRM on account holder satisfaction.

The results of this study have significant managerial implications to commercial bank managers that develop and implement CRM strategies. With regard to the study findings, commercial bank managers should enhance their technology based CRM strategies in order to satisfy customers. In terms of technology, bank managers should implement self-services technologies that are user friendly, thus the need to training on mobile banking. Banks have invested heavily on technology but need to train customers and bank personnel on services such as mobile banking to increase accessibility and convenience of services. Therefore, commercial bank managers who want to boost their account holder satisfaction and performance should develop CRM strategies that focus on technology based CRM that is easy to use, convenient and accessible. Commercial banks in Kenya play a critical role in the economy by contributing significantly to the realization of Kenya Vision 2030 through savings, wealth mobilization and massive job creation. Consequently the Central Bank of Kenya and the government should develop policies relating to technology based CRM and customer satisfaction in order to protect account holders, employees and the entire financial sector.

\subsection{Suggestions for Further Research}

The primary goal of this study was to establish the relationship between technology based CRM and satisfaction of account holders in commercial banks in Nairobi City County in Kenya. The study used technology based dimensions such as ease of use, ATM, accessibility, convenience and did not take into account other factors such as environmental, organizational and other technology related factors that affect customer satisfaction. The study established that technology based CRM had a positive and significant effect on satisfaction of commercial banks account holders. Future studies should find other dimensions of technology based CRM and use other variables to further validate the current model. There is need for further research using mediating and moderating variables in the model so as to improve its statistical significance. Although this research met its objectives, there is need for future empirical studies to replicate this study in other service industries such as insurance, airlines and medical service using different a research design such as time series.

\subsection{Acknowledgement}

The author is grateful to Dr.Samuel Maina and Dr. Linda Kimencu for their insights, devotion, scholarly critique, guidance and support towards the completion of this study.

\section{REFERENCES}

Boone, L. \& Kurtz, D. (2013). Contemporary marketing. Cenage.

Bougnerra, A. \& Mzough, M.N. (2011). Relationship marketing: The forgotten consumer. International Journal of Business and Social Science 2(6), 2010.

Boyle, M. J. (2004). Using CRM software effectively. CPA Journal, 74 (7), 17.

Buttle, F. (2006). Relationship Marketing: Theory and Practice. Paul Chapman Publishing, London, 1 - 16.

Central Bank of Kenya, (2014). Annual Economic Report.

Central Bank of Kenya (2015). Central Bank of Kenya . Directory of commercial banks and mortgage companies. www.centralbank.go.ke.

Chen, J.I. \& Popovich, K. (2003). Understanding customer relationship management: People, processes and technology. Business Process Management Journal, 9(5), 672-688.

Christopher, M., Payne, A. \& Ballantyne, D. (1991). Relationship marketing: Bringing quality, customer service and marketing together, Butterworth- Heinemann, Oxford.

Cooper, D. R. \& Schindler, P. S. (2003). Business Research Methods, $8^{\text {th }}$ Ed. New Delhi: Tata McGraw-Hill Publishing Company Ltd.

Eckerson, W. \& Watson, H. (2000). Harnessing customer information for strategic advantage: Technical challenges and business solutions. Special report, The Data Warehousing Institute Chatsworth, CA.

Fecikova, I. (2004). An index method for measurement of customer satisfaction. The TQM Magazine, 16(1), $57-$ 66.

Fickel, L. (1999). Know your customer. CIO Magazine, 12(21), 62-72.

Field, A. P. (2009). Discovering Statistics Using SPSS (2 ${ }^{\text {nd }}$ Ed.) London: Sage.

GoK (2008). Companies Act (Cap 486, 2008). Kenya Law Reports. National Commission for Law Reporting. Government Printer, Nairobi.

GoK (2012). Banking Act (Cap 488, 2012). Kenya Law Reports. National Council for Law Reporting. Government printer, Nairobi.

Hansemark, O.C. \& Abinson, M. (2004). Customer satisfaction and retention: The experiences of individual with employees. Managing Service Quality, 14, 1.

Jain, R., Jain, S. \& Dhar, U. (2003). Measuring customer relationship management. Journal of Service Research, 
2 (2), 97-109.

Jeong,Y.\& Lee,Y.(2010). A study of customer satisfaction and customer loyalty of furniture purchasers in on-line shopping. Asian Journal on Quality, 11(2),146-156

Maina, S. M. (2014). Effect of perceived value and demographics on the relationship between consumer national ethnocentrism and willingness of University of Nairobi Community to buy commercial banking services in Kenya. Unpublished Phd Thesis, University of Nairobi.

Malhotra, N., Hall, J., Shaw, M. \& Oppenheim, P. (2002). Marketing Research: An Applied Orientation. PrenticeHall:Sydney.

Narteh, B. (2014). Service quality in automated teller machines: An empirical investigation. Managing Service Quality- An International Journal, 23 (1), 62-89.

Parvatiyar, A. \& Sheth, J. N. (2002). Customer relationship management: Emerging practice, process and discipline. Journal of Economics and Social Research, 3(2).

Payne, A. \& Frow, P. (2005). A strategic framework for customer relationship management. Journal of Marketing, 69 (4), $1-17$

Peppers, D., Rogers, M. \& Dorf, B. (1999). Is your company ready for one-to-one marketing? Harvard Business Review, $151-160$.

Rogelberg, S. \& Santon, J. (2007).Understanding \& dealing with organizational survey non-response. Organizational Research Methods, 10, 195-209.

Roy, S. K. \& Ganguli, S. (2011). Generic technology-based service quality dimensions in banking. International Journal of Bank Marketing, 29 (2), 163 - 189.

Sadek, H. \& Tantawi, P. (2009). Measuring customer relationship management and its relationship with satisfaction in the Egyptian banking sector. Arab Academy for Science, Technology and Maritime Transport, Egypt.

Salhieh, L.Doleh, A.J \& Hijazi, N. (2011). The assessment of e-banking readiness in Jordan. International Journal of Middle East Finance Management, 4 (1), 325-342.

Saunders, M. N., Lewis P. \& Thornhill, A., (2009). Research methods for business students. Pearson Education, India.

Siam, A. (2006). Role of the electronic banking services on the profits of Jordanian Banks. American Journal of Sciences, 3 (9), 1546 - 9239.

Sin, L.Y.M., Tse, A.C.B. \& Yim, F. H.K. (2005). CRM: Conceptualization and scale development. European Journal of Marketing, 39(11/12), 1264 - 1290.

Tan, M. \& Teo, T. (2000). Factors influencing the adoption of electronic banking. Journal of the Association of Information Systems, 1 (5) 1 - 42.

Thuo, J. K. (2011). Customer relationship management and competitiveness of commercial banks in Kenya. Unpublished $\mathrm{PhD}$ Thesis, University of Nairobi.

Thurkar, R., Summey, J. H. \& Balasubramanian, S. K. (2006). CRM as a strategy: Avoiding the pitfalls of tactics. The Marketing Management Journal, 16 (2), 147 - 154.

Yamane, T., (1967). Statistics: An Introductory Analysis (2nd ed.). New York: Harper and Row. 